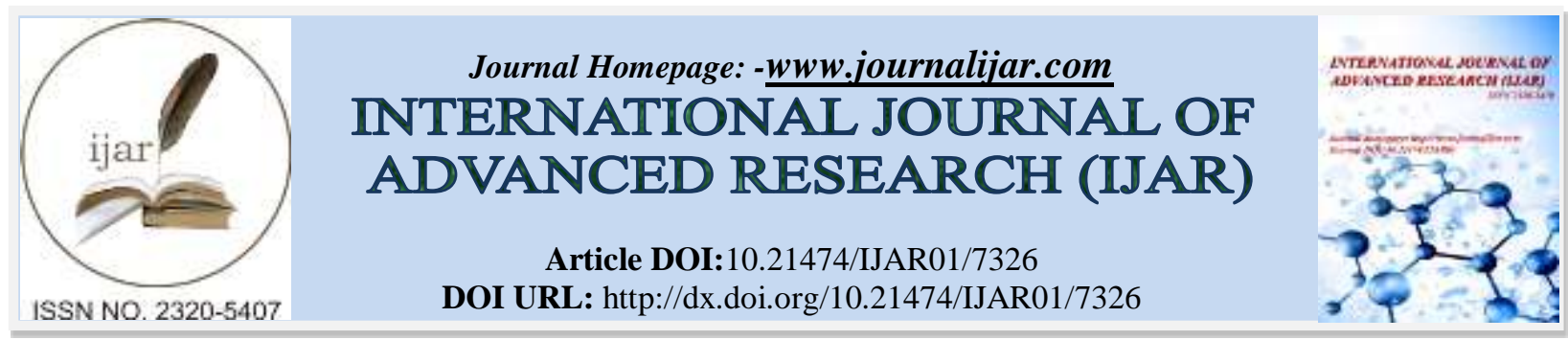

RESEARCH ARTICLE

\title{
EFFECTS OF MONO-GRADE TEACHING AND LEARNING AT PRIMARY LEVEL SCHOOLS.
}

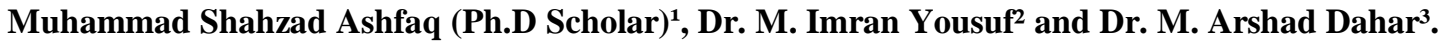

1. Faculty of Social Sciences, Pir Mehr Ali Shah, Arid Agriculture University, Rawalpindi - Pakistan.

2. Chairman, Department of Education, Pir Mehr Ali Shah, Arid Agriculture University, Rawalpindi - Pakistan.

3. Assistant Professor, Faculty of Social Sciences, Pir Mehr Ali Shah, Arid Agriculture University, Rawalpindi Pakistan.

\section{Manuscript Info}

Manuscript History

Received: 20 April 2018

Final Accepted: 22 May 2018

Published: June 2018

\section{Keywords:-}

Mono-grade teaching, effects of teaching, primary level schools, teacher's perception.

\section{Abstract}

The teachers are extraordinary wellsprings of learning, thriving and edification to which anybody can be profited for entire life. They serve as the genuine light in every body's life as they help the understudies to make their courses in the life. The teaching profession is considered as the best and perfect duty in world as they give caring obligation to shape somebody's life. Before going to the classroom, a great teacher guarantees his/her objectives of training on regular routine. Each teacher has diverse characteristics of showing their understudies. They change in their insight, abilities, and mentalities in showing particular subjects. They attempt their best and do all endeavors in helping us to accomplish our objectives in life. The aim of present study is to investigate the effects of mono-grade teaching and learning at primary level schools. The objectives of the study were: 1) To find out the effects of mono-grade teaching and learning in primary schools. 2) To find out which method is easy for learning outcome for students in primary school. 3) To discover in which method students can improve their grade and develop their social skills. The descriptive survey method was used in study. The target population was comprised of One thousand five hundred and seventy six (five hundred and thirty one male one thousand and forty five female) primary teachers of government schools. A sample of two hundred teachers (both male and female), two teachers from each government primary schools were selected. Research questionnaire was developed on likert scale for gathering the data on the basis of teacher's perception on the organizational effects of mono-grade teaching and learning. The collected data were analyzed through SPSS 21 . The score of responses were tabulated in to the frequencies and represented in percentage and chi square test was performed. The results and findings of the study reveal that the majority of teacher's perception regarding the student learning in mono-grade teaching strategies is statistically very high indication.

Copy Right, IJAR, 2018,. All rights reserved. 


\section{Introduction:-}

Teaching is an imperative device used for guideline in various circumstances. It is the method for correspondence received in a dynamic and solid environment. Teacher is likewise the coordinator of learning circumstances and transmits science to social community. Some time teacher might be called as a pioneer who assumes a part to change the awful standards of society into the great one. For his past encounters they offer information to understudies and make the establishments of country. Teachers are extraordinary wellsprings of learning, thriving and edification to which anybody can be profited for entire life. They serve as the genuine light in every body's life as they help the understudies to make their courses in the life.

As social authentic development in the fifteenth and sixteenth century, humanism and renaissance additionally figured out how to put talk on a platform in schools, college, writing, political legal field, too with in religion. In this period - the time of recorded success of talk - mono rationale technique was created, particularly in restored fields arithmetic, history, topography, mechanics and stargazing. In any case, the improvement of the said field in the hypothesis and routine with regards to talk proceeded with moderately autonomously in the hundreds of years to come. Changes were presented in talk and instructional method, having decided the heading of the advancement of mono-grade teaching technique. The progress in the number of learners requiring particular education and the usage of inclusive education have turned into a universal motivation. Broad education takes a look at how all learners, paying little attention to their individual contrasts, could be taught in regular standard classrooms (Makoelle, 2013). Education is a basic part of society. In North America, and the United States and Canada particularly, training is a key right delighted in by every subject. While the level of gaining differs extraordinarily from individual to individual, class to class, school to school, and ward to purview, the instructive conveyance show is strikingly comparable all through the world comprising of either the multi-grades or mono-grade classroom method (Little, 2004a). The usage of either multi-grade or mono-grade is definitely not continuously in view of amplifying learning openings (Vincent, 1999), yet in light of the money related substances of directing a school, educator supply, and understudy enlistment (Blum and Diwan, 2007, Little, 2008).

A class that contains understudies of a solitary evaluation level, yet ordinarily of blended capacities is called monograde class. Ordinarily such classes contain understudies of a comparative age range, yet in nations where reiteration and increasing speed are regular, a mono-grade class may likewise be blended age. The term single age class is infrequently used to recognize classes that contain understudies of a predetermined area harmonious with grade level (Aksoy, 2007). It is a class that the evaluations compare intimately with the age of the students and as a rule involve learners who have birthday celebrations inside one date-book year, a solitary Instructor more often than not educates each class at a given time. In a mono-grade teaching school, learners are assembled by review with a particular instructor appointed to each grade, or class inside that review. By complexity, students in a multi-grade school are not assembled and educated in independent classes; learners of blended ages, capacities, and in various evaluations are all in attendance in the meantime, in a similar classroom with one educator (Jordaan and Joubert, 2007, Joubert, 2010, Little, 2001, Tsolakidis, 2010). It appears that multi-grade teaching, as practice, is not one of decision but rather a need to give instruction to learners in remote areas. Thus, so as to make training financially feasible and to give access to instruction, the multi-grade training model is by all accounts the main choice in numerous rustic ranges (Bhardwaj, 2008 and Little, 2006).

Mono-grade showing strategy has a diverse status and position for the most part contingent upon the outrageous methodologies of offering preferred standpoint to one of the components of pedantic triangle - instructor, understudy or educating content. In specific times of the improvement of sorted out types of childhood and training, the highlight was on the educator and his/her exercises; as a result, critical place and time had a place with a monolog lessened to verbal introduction of an instructor. Dull realism kept up the complement on the monolog of an instructor, however with a modified hugeness. It was vital to gain however many actualities as could reasonably be expected with the goal that mono-grade teaching was satisfactory to the degree it guaranteed such an amount of information. With a move of enthusiasm from the teacher and instructing substance to an understudy, i.e. a child and his/her needs, mono-grade teaching was placed in a moment arrange in connection to the showing techniques opening more space for youngsters to do self activity. They were incompletely supported reactions on the cost of the accentuation on verbal introduction joined with frontal instructing. The issue was not in the showing mono-grade, but rather in its dishonorable execution, and to a degree in the endeavors to "legitimize" numerous shortcomings in instructing as indicated by verbalism educating in verbalism gotten from such an educating. 
Classroom administration is an administrative aptitude which includes arranging, educating, driving, controlling, sorting out and overseeing (Walters, 1991). Classroom administration is most certainly not simply guaranteeing great teach, get ready and arranging the lesson or masterminding work areas in a distinctive example. It involves each activity that outcomes through a decent learning environment in the classroom. Educators teach in multi-grade classrooms ought to guarantee a decent learning climate in their classrooms for viable figuring out how to occur. Walters (1991), distinguishes components of feasible classroom methods of teaching for educators, classroom condition and alternative methods. Instructors must arrange their coaching. Pictures and graphs have to be shown in the classroom and work areas must be well-organized. Spotlessness has to be kept up by any means times and assets legitimately organized to permit simple get to. It is likewise vital that learners be given classroom system which will uphold teaching.

A link is infrequently made between the issues confronting the multi-grade classroom educator and those going up against the mono-grade teacher. Especially in creating nations, mono-grade classrooms might be described both by outrageous blended capacity and wide age run if there is a considerable measure of grade level redundancy. Thus, the sorts of issues are comparable. In mono-grade classrooms, nonetheless, they may not be perceived as issues. It is basic in many creating nations for guideline to be exceptionally educator coordinated and to incorporate constrained open doors for understudy cooperation (Lockheed, and Verspoor, 1991). In the first place, educational programs change is one path in which multi-grade educating can be made more powerful. The sort of change proposed typically concentrates on the explanation that a gathering of children in any one classroom will be creating at various paces. The improvement of particular learning goals, together with more adaptable ways to deal with maintenance and advancement, might be one route in which understudies of blended capacities in mono-grade classrooms can be permitted to travel through the framework at a pace proper to them, and furthermore to accomplish the base learning destinations that the framework sets.

In second place, mono assessment instructors in numerous nations need to decrease their reliance on 'chalk and talk' and to expand the scope of instructional systems that they usually utilize. Some of these methodologies are those advanced in the multi-grade setting. They incorporate companion direction, helpful gathering work, and free selfcontemplate. The third, path in which mono-grade instructor's deal with their classes ought to at times turn out to be more similar to the facilitator part recommended in the multi-grade class. This includes changing the route in which the classroom is sorted out by expanding access to self- contemplate regions, for example, classroom libraries, and advancing more gathering work free of the educator. Gatherings might be framed by capacity or by mixed capacity, contingent upon the instructor's motivation for guideline.

Education is about understudy learning. The association of the classroom to give education to understudies may come as a mono-grade or multi-grade classroom. In numerous locales, multi-grade training is the main open door for learning (Berry and Little, 2006). In any case, given that examination on the impacts of multi-grade teaching on understudy accomplishment is uncertain and questionable, deciding whether multi-grade training is a practical contrasting option to mono-grade instruction is a subject that required further contemplate (Brinegar, 2010, Fosco, Schleser. and Andal, 2004, Little, 2008).

The mono-grade classroom is the most broadly perceived type of instructive association for classrooms. At the point when offered as another option to the mono-grade classroom to guarantee a maintained instructive program for rustic understudies, and customarily, poor locales multi-grade classrooms are gainful in view of their reasonable money related points of interest and keeping up classrooms despite declining or little understudy enlistments (Little, 2004b). Moreover, multi-grade teaching is a sensible, and now and then best, elective on account of the required individualized instructing through separated direction (Tomlinson, 2005), and the advantages of competent companion joint effort (Fawcett and Gorton, 2005).

Berry keeps up that multi-grade schools are especially successful at advancing the perusing advancement of low accomplishing understudies, somewhat on account of contrasts in the way to deal with direction in multi-grade and mono-grade classrooms. Berry says that mono-grade classrooms are portrayed by undifferentiated entire class educating; nonetheless, in multi-grade classes understudies have greater chance to participate in little gathering work (Berry, 2001).

This current exercise is a supply of educator shares in view of the evidence of the quantity of understudies selected in the school, absence of the necessary number of understudies in the schools of isolated and provincial territories all 
over in the country frequently brings about the insufficient supply of teacher amounts for the quantity of classes. Due to the deficiency of teachers and understudies of a little town does not permit by lead the foundation of primary school in the remote precipitous and sloping districts, multi-grade educational structure of essential training has been particularly in trend in these areas of the Kingdom (Apeid/Unesco, 1989).

Multi-grade classes can change as far as the multifaceted nature of the instructional methodologies utilized. For instance, students of various ages might be intentionally gathered for one subject with the goal of lessening heterogeneity of capacity and making it less demanding to educate the entire class. Then again, multi-grade gathering might be presented over the educational programs. This should be in mind that the last goal is to exploit the apparent focal points of blended age classes for concentrating on the formative needs of individual children.

The progress in the number of learners requiring particular education and the usage of inclusive education has turned into a universal motivation. Broad education takes a look at how all learners, paying little attention to their individual contrasts, could be taught in regular standard classrooms (Makoelle, 2013).

Multi-grade classrooms are methods for keeping up teaching and schools considering declining understudy enlistment, or in a few occurrences in inward city groups those outcomes in either going to multi-grade classes or no school by any stretch of the imagination (Berry and Little, 2006). Multi-grade preparation is an inescapable instructive association that can be found all through the world in both industrialized and creating countries (Little, 2004a). In particular, examine from the United States and Canada anticipated the predominance of multi-grade instruction to build (Chapman, 1995). Moreover, multi-grade teaching is prone to increment significantly advance into the future as a practical other option to the mono-grade classroom (Mulryan-Kyne, 2007). It given the wide difference in usage strategy of multi-grade teaching, look into on the impacts of this classroom association on understudy accomplishment stays uncertain (Brinegar, 2010), and it require of further research (Little, 2008).

Multi-grade teaching is by and largely found in schools where only one teacher is available or an institution have only two teachers, here and there even this method can also be seen where in a school have three teachers, multilevel classes in higher foundations, no graded early adolescence training units and unique multilevel collection of understudies. In such schools enrolments is a rule modification within ten to hundred. Multi-grade teaching is not a response to meeting educator deficiencies in the instructive frameworks yet is a methodology to enhance the nature of training in rustic groups. Looking to the socio-social milieu in which the little schools with multi-grade educating are working, these schools could be the focuses of social improvement and group conscientious and the requirement for enhancing their working is far more noteworthy than perceived.

\section{Background:-}

The idea of a teacher understudy instructive model is an authoritative structure that strings all through history. Instructive structures shift through time and locales. The cutting edge organized mono-grade class comprising of an accomplice of age-comparative understudies follows back to the nineteenth century (Pardini, 2005). The more current day classroom is more than the basic securing of topic (Dewey, 1916 and Vgotsky, 1978).

Multi-grade teaching shows an inescapable exercise which emerges through predetermined amount of understudies and classrooms in little and dispersed resolution territories where populace thickness is low and is seen as a framework that should be canceled (Aksoy, 2007). Multi-grade teaching is coordinated to parallel value of change. APEID/UNESCO (1989), has properly said that multi-grade teaching does not a response to gathering educator lack in an instructive framework yet is a procedure for enhancing of nature of training in country groups. Multi-grade classes contrast from customary classes where each class has its particular grade with its own particular educator and classroom. On account of multi-grade teaching, this is eluded as the course of action of a situation in which understudies of no less than two evaluations are educated jointly by an instructor in one classroom. The other situation, which is not quite the same as this, has isolate classrooms for various evaluations, yet not the required number of classrooms, where the single educator instructs these evaluations by going to the different classrooms in meantime. This kind of teaching course of action is also called multi-class educating, which is the prevailing component of teacher in rare schools other than the normal schools.

The multi-grade schools utilize similar educational modules, have similar states of administration, a similar national performing and have indistinguishable arrangements from other government funded schools in the nation. This recommends the educational modules substance, instructing and learning materials are intended for mono-grade 
classes. It is against this foundation that the grade class was done to comprehend educators' difficulties on multigrade showing system in rustic schools. Besides, insufficient physical workplaces of primary schools, absence of monetary assets, reluctance of teachers to teach in rustic/isolated regions and absence of prepared educators in multiclasses educating are likewise alternate explanations for the required utilization of multi-grade teaching in the nation. In the main circumstance, two evaluations are situated in one classroom and the educator offers assignments to one grade while educating alternate evaluations and the other way around. In the other circumstance, one educator assumes the liability of showing more than one grade in the meantime. In the last circumstance, every evaluation be situated by a different classroom and the instructor educates every grade in a different classroom.

Multi-grade educators ought to be prepared the techniques that assistance to create relations among the school and the learners group. The difficulties of multi-grade educating and learning are that the nation-wide educational modules improvement and educators preparing programs are for the most part in view of a model of mono-grade educating and learners in accepted multi-grade schools need to fight for themselves. The challenges confronted by instructors showing multi-grade classrooms radiates from educational modules outline, the educators themselves, learning and instructing form, school conditions, learners, educators preparing, course books and support. Teacher in multi-grade classrooms are required to actualize the educational programs for mono-grade classrooms and that makes a significant amount of challenges for the instructors included.

\section{Purpose:-}

In this modern age when the world is discovering life on Marse, the educational system is key point to success for every nation of the world. Any nation which does not follow modern and partially good teaching techniques will not be contends the rest of world. In Pakistan a number of teaching methodologies are working. Every methodology has its own scope of learning, some are old methodologies and some are modern methodologies. Some people are supporting old techniques of teaching and some are supporting modern techniques of teaching but none of them have enough analysis and study that prove that which methodology is better. After looking at above mentioned problem, this research was conducted to watch out about two teaching techniques through a detailed study and to find out which method is significantly better for our educational system. The two under study strategies are monograde and multi-grade method of teaching. The multi-grade method is applied due to shortage of teachers and sometime due to shortage of qualified teachers. In this research the researcher had a better strategy of student's learning from both the above mentioned methods. In this research the researcher tried to discover its effect on student achievement and more especially the formative years of literacy for primary students by teaching methodology in which method of teaching students can enhance their knowledge. Which method is liked by parents, which method is easy for learning outcome of students, by which method students can improve their grades and through which method students can develop their social skills.

The purposes behind the presentation of multi-grade classrooms are most certainly not generally in light of the unselfish philosophy of expanded individual understudy learning. Rather, the usage of multi-grade classrooms is for the substantially more non instructive reasons of budgetary reasonability, Little, (2004), independent of its impact on understudy learning. At the point when multi-grade instruction is being proposed the examination does not give indisputable proof to help instructive partners in the basic leadership prepare if in fact it is a reasonable contrasting option to the mono-grade classroom. The usage of either multi-grade or mono-grade is definitely not continuously in view of amplifying learning openings, Little (2008), Blum and Diwan (2007), Vincent (1999), yet in light of the money related substances of directing a school, educator supply, and understudy enlistment

Outside the United States and Canada, while exact information is hard to confirm, in any case multi-grade instruction is an extremely common and standard instruction practice. This reality in any case, an investigation of the adequacy of multi-grade versus mono-grade understudy accomplishment levels is absolutely apropos. While multi-grade classrooms might be an ordinary that's more, unavoidable instructive practice in both industrialized and creating nations.

Additionally depicted restrict discoveries that announced constructive outcomes and negative impact, and no critical contrasts in understudy learning in multi-grade and mono-grade classes. Research in multi-grade teaching, especially as it identified with understudy accomplishment, remains to a great extent unexplored. 


\section{Significance:-}

The current study contribute to be educational research if mono-grade teaching is an equally effective alternate to multi-grade teaching, it is likely to be in the best interest of the students. The study will be beneficial for government schools teachers for improvement in their performance and for students by providing guideline for improving the educational standards of the students and increase achievement in their understanding regarding teaching methodology.

\section{Objectives:-}

The objectives of the research study were as under:

1. To find out the effects of mono-grade teaching and learning.

2. To find out which method is easy for learning outcome of students.

3. To discover in which method students can improve their grade and develop their social skills

\section{Literature review:-}

The research literature on classroom associations in instructive frameworks that are basically unique in relation to the conventional mono-grade class comprising of likeminded, comparable matured people, uncovered a scope of terms. The general term for the customary classroom instructed by one educator is mono-grade training (Little, 2004a). At the point when referencing classrooms, which are not mono-grade, the writing for the most part alludes to classrooms as multi-grade or multi-age (Berry and Little, 2006). In this manner, every classroom association, which is not mono-grade in configuration, has its own exceptional instructive logic. The mono-grade classes remain solitary and unmistakably set apart from these other classroom associations.

In the modern age when the world is discovering the advancement in the life the educational system is key to success for every progressive country. The study followed, the multi-grade classroom theory varying grades, combines students, development and knowledge abilities. In multi-grade classes students deserve the individual attendance of each particular class. Cornish described that mono-grade classes are rigid educational framework the modern classrooms are the important part of the educational process in social interaction, Cornish (2009). The continuity of the peer collaboration is the effective part of teaching and in processes of learning. The importance, in fact, of peer collaboration is critical part of the educational theory, which student could not thoroughly learn without peer knowledge as in the multi-grade classes.

In numerous social orders over the world multi-grade classrooms are not just the main other option to mono-grade classes, additionally truth be told, the main instructive structure accessible by any means (Blum and Diwan, 2007). That is, if understudies don't get a multi-grade training, at that point they don't get any training what so ever (Berry and Little, 2006). Outside the United States and Canada, while exact information is hard to confirm, in any case multi-grade instruction is an extremely common and standard instructive practice. This reality in any case, an investigation of the adequacy of multi-grade versus mono-grade the student's achievement levels is absolutely apropos. While multi-grade classrooms might be an ordinary which more, unavoidable instructive practice in both industrialized and creating nations, as beforehand noticed that does not mean the examination is decisive on the benefits of the multi-grade instructive practice (Brinegar, 2010, Little, 1995, Little, 2008).

A determination to maintain schools in decrease societies for small and rural areas, mono-grade teaching is an alternate to the traditional multi-grade classroom (Kapplern and Roellke (2002). Attention on discriminated instruction and potentials of present opportunities for communication and co-operation with more capable peers (Tomlinson, 2005). Fawcett and Garton (2005) and Gnadinger (2008), multi-grade teaching could be a positive alternate to the mono grade classroom (Mulryan-Kyne, 2007). However, research on mono grade and multi-grade classroom teaching and their difference in teaching achievement remains conclusive and reliable, Brinegar (2010), Fosco, Schleser, and Andal, (2004) and Little (2008). So the specific purpose was if there is a difference in learner's achievement between mono-grade and multi-grade classes, Cornish (2009).

Education is important tool for the society. In foreign countries like, United States of America and Canada, where the education is fundamental right and their citizen are being enjoying this right. Where class to class, person to person jurisdiction to jurisdiction and school to school varies great learning level in delivery of education, Kappler and Roellke (2002), model strikingly similar in the entire world either consisting of the mono-grade or multi-grade classrooms. Such as in the study, Veeman (1995), Little (2004a), Gene and Miller (2005), learning opportunity was not minimized by implementing the mono-grade or multi-grade on the basis of financial constrain, school 
administration, supply of the teachers and enrolment of the student. It is pertinent to mentioned that the level of the student's achievements they certainly the effectiveness of the mono-grade versus multi-grade method of teaching was better. In developing and industrial countries the multi-grade classrooms pervasive practice of education is a normal routine (Brinegar, 2010).

Little (2007), recognize ways to deal with the educational programs in multi-grade instructing as multi-year educational modules ranges, semi mono-grade and learner and material-focused. In multi-year educational modules traverses units of educational programs content are spread crosswise over a few evaluations as opposed to one. Learners work by normal points and exercises. In separated curricular the similar subject or point is secured with every one of the learners and learners in every review participate in learning errands proper to their level of learning (Little, 2007).

Cornish as already discussed that mono-grade classes are rigid educational framework the modern classrooms are the important part of the educational process in social interaction Cornish (2009). The continuity of the peer collaboration is the effective part of teaching and in processes of learning. The importance, in fact, of peer collaboration is critical part of the educational theory, which student could not thoroughly learn without peer knowledge as in the multi-grade classes.

Such as in the study, Tomlinson (2005), the suggestion given that the unique need of every learner and individual the graded classrooms should be replaced to non-grade classrooms. The optimal student learning should not be minimized. Mono-grade classrooms are more appropriate learning approach. From a theoretical perspective, the mono-grade classrooms which focus the education theory may offer appropriate organizational effect on the pupils.

Classroom administration is an administrative aptitude which includes arranging, educating, driving, controlling, sorting out and overseeing (Walters, 1991). Classroom administration is most certainly not simply guaranteeing great teach, get ready and arranging the lesson or masterminding work areas in a distinctive example. It involves each activity that outcomes through a decent learning environment in the classroom. Educators teach in multi-grade classrooms ought to guarantee a decent learning climate in their classrooms for viable figuring out how to occur. Walters (1991) distinguishes components of feasible classroom methods of teaching for educators, classroom condition and alternative methods. Instructors must arrange their coaching. Pictures and graphs have to be shown in the classroom and work areas must be well-organized. Spotlessness has to be kept up by any means times and assets legitimately organized to permit simple get to. It is likewise vital that learners be given classroom system which will uphold teaching.

In a survey it is apparent that understanding when multi-grade classes had no predictable contrast in achieving scores in centre branches of knowledge perusing, arithmetic and language in comparison of mono-grade classroom method. The improvement of particular learning goals, together with more adaptable ways to deal with maintenance and advancement, might be one route in which students of different capacities in mono-grade classrooms can be permitted to travel through the framework at a pace proper to them, and furthermore to accomplish the base learning destinations that the framework sets. Multi-grade ponders have discovered beneficial outcomes on such things as social advancement and mental improvement, Pratt (1986), and Lloyd (2002). The exploration, which is the investigation, invalidated the discoveries that multi-grade teaching has no impact on understudy accomplishment. The finishes of the examination found that while there is an affirmation and concession in the examination that for the most part the writing has held there are no huge contrasts in understudy accomplishment in multi-grade classes contrasted with mono-grade classes, all things considered multi-grade classes have a little negative impact on accomplishment. The examination by Mason and Burns (1996) stands about alone in the conclusion that multi-grade training negatively affects the understudy accomplishment.

\section{Methodology:-}

The research methodology covers research design, population, sampling, instrumentation and procedure of data collection for the current study. The descriptive survey research method was applied to carry out the study (Best $\&$ Kahn, 1998). Gay, (1976), stated that the descriptive research method is mostly concerned with the conditions that prevail, that exist, practices, attitude that are held, beliefs and trends that are developing processes and that are ongoing. 


\section{Population:-}

The target population of the study was comprised of one thousand five hundred and seventy six (five hundred and thirty one male one thousand and forty five female) primary teachers of government schools of (Tehsil Gujar KhanRawalpindi) Pakistan. To determine an appropriate sample size, an updated list of all schools in (Tehsil Gujar KhanRawalpindi) Pakistan was collected from education department. The measure of 'population' in research study must understand which concerned the subjects or data items that must be included in the study, giving the specific and relevant circumstances (Polit \& Hungler, 1999).

\section{Sampling procedures:-}

Sampling is a research technique that used to select a certain number of subjects from a target population as a representative of population (Borg and Gall, 1986). A sample of two hundred teachers (both male and female) from government primary schools was taken. The selection procedure of a portion of the target population to represent it the entire population is known as sampling (LioBiondo-Wood \& Haber, 1998; Polit \& Hungler, 1999). For the study interest convenience sampling is deemed most suitable (De Vos, 1998).

\section{Research Instrument:-}

The questionnaire tool was used. The questionnaire was developed to collect the information. The items of the questions were drawn according to five-point likert scales, "strongly agree, agree, neutral, strongly disagree and disagree" (Post, D. et al., 2009). Mugenda, (2003), confirmed that the use of questionnaires is the most common instrument in the research of social science study. They said that well organized questionnaires are advantageous because the respondents can see their way around with comfort and that they are easy to compute (Annexure 'A').

\section{Validity:-}

For validation of questionnaire conducted a pilot study in boys and girls primary schools. According to Borg \& Gall, (1989), a researcher can conduct a pilot study in two or three cases. The purpose of the preliminary test was to help the researcher to identify the elements that considered inappropriate and make the necessary corrections, examine the answers to check the level of ambiguity of the questions and to evaluate the responses of participant to determine the percentage. The ambiguous items were modified in more appropriate forms. It helped to determine the time required to manage the instrument. Based on the consultation with the experts, the study selected 38 items from the questionnaire and finalized for the administration. As stated by Gay, L. R., (1987), the descriptive survey research method involves gathering data to evaluate hypotheses or to answer questions about the status of the study.

\section{Reliability:-}

The research instrument was delivered to same group of participants twice in the pilot study. The scores of all tests were correlated to obtain the use of the reliability coefficient SPSS. The value of Chronbach's coefficient of Alpha of the instrument was calculated .996 which was considered to be quite suitable for the study at large scale (Gay, 2002). The Alpha 996 shows that the given 38 questions have higher internal consistency. A value equal to .700 or high is acceptable in social sciences research work.

Reliability Statistics:-

\begin{tabular}{|c|c|}
\hline Cronbach's Alpha & N of Items \\
\hline .996 & 38 \\
\hline
\end{tabular}

\section{Data Collection:-}

During the research, investigator was personally visited the schools to get the data from selected sample of the study. The data collection was completed in seven to eight weeks. Straus and Myburgh, (2000), described that collection of data is a basic key and important prospective between the investigator and respondent, collection of data is an art for the researcher from the respondent in mainly efficient means. Tustin, (2006), said that one time the investigator notices the requirement of major research data and has conveyed research objectives and facts requirements, the collection of data is conducting through questioner with chosen objects.

\section{Statistical Analysis:-}

Gay, L. R., (1987), indicated the importance of the data analysis techniques and its emphasis that "the research plan must include a description of the technique or the statistical techniques used to analyze the data". The collected data were tabulated in the forms of frequencies. The frequencies were presented into scores that assigned the percentage values of the scales each of five responses (using the Likert scale). Borg and Gall, (1998), described that the most 
commonly used and the confirmed standard pattern is the percentage. The collected data were analyzed by entering the data into a statistical package for the social sciences 21 . The percentage and chi square tests were performed for analysis the data (Mirvaliev, M, 1987).

Case Processing Summary:-

\begin{tabular}{|c|c|c|c|}
\hline & & $\mathrm{N}$ & $\%$ \\
\hline \multirow[t]{3}{*}{ Cases } & Valid & 200 & 100.0 \\
\hline & Excluded $^{\mathrm{a}}$ & 0 & .0 \\
\hline & Total & 200 & 100.0 \\
\hline
\end{tabular}

$$
\chi^{2}=\left[\frac{(O-E)^{2}}{E}\right]_{\text {Where, }} \chi^{2}=\text { Chi-Square test } \mathrm{O}=\text { observed value } \mathrm{E}=\text { expected value. }
$$

\section{Results and Findings:-}

Table 1:- Scores of teacher's responses about students learning.

\begin{tabular}{|c|c|c|c|c|c|c|c|c|c|}
\hline \multirow[t]{2}{*}{ Aspects } & \multirow[t]{2}{*}{ SA } & \multirow[t]{2}{*}{ A } & \multirow[t]{2}{*}{$\mathrm{N}$} & \multirow[t]{2}{*}{ DA } & \multirow[t]{2}{*}{ SDA } & \multirow[t]{2}{*}{$\mathrm{N}$} & \multirow[t]{2}{*}{ Df } & \multicolumn{2}{|c|}{ Chi-Square } \\
\hline & & & & & & & & $\chi^{2}$ & Sig \\
\hline $\begin{array}{l}\text { Teaching enhances increased access to } \\
\text { education }\end{array}$ & 63 & 120 & 10 & 6 & 1 & 200 & 4 & 262.650 & .000 \\
\hline $\begin{array}{l}\text { Teaching enhances increased access to } \\
\text { education }\end{array}$ & 63 & 120 & 10 & 6 & 1 & 200 & 4 & 262.650 & .000 \\
\hline $\begin{array}{l}\text { Teaching enhances improved performance to } \\
\text { education }\end{array}$ & 65 & 68 & 55 & 12 & 0 & 200 & 3 & 40.360 & .000 \\
\hline $\begin{array}{l}\text { Learning outcomes in multi-grade classes is } \\
\text { better than in the mono-grade classes }\end{array}$ & 37 & 70 & 55 & 30 & 8 & 200 & 4 & 56.450 & 000 \\
\hline $\begin{array}{l}\text { Students learn better in multi-grade than } \\
\text { mono-grade classes }\end{array}$ & 29 & 66 & 36 & 52 & 17 & 200 & 4 & 37.150 & .000 \\
\hline Students are more motivated in learning & 49 & 65 & 46 & 33 & 7 & 200 & 4 & 47.000 & .000 \\
\hline $\begin{array}{l}\text { In grade classes, syllabus can be completed } \\
\text { in time }\end{array}$ & 46 & 74 & 46 & 26 & 8 & 200 & 4 & 45.850 & .000 \\
\hline $\begin{array}{l}\text { Teaching is promoting group work and } \\
\text { collaboration among students }\end{array}$ & 20 & 26 & 46 & 68 & 40 & 200 & 4 & 61.200 & .000 \\
\hline $\begin{array}{l}\text { In teaching students give timely feedback to } \\
\text { their teachers }\end{array}$ & 58 & 80 & 30 & 18 & 14 & 200 & 4 & 79.600 & .000 \\
\hline & 367 & 569 & 324 & 245 & 95 & 1600 & & & \\
\hline
\end{tabular}

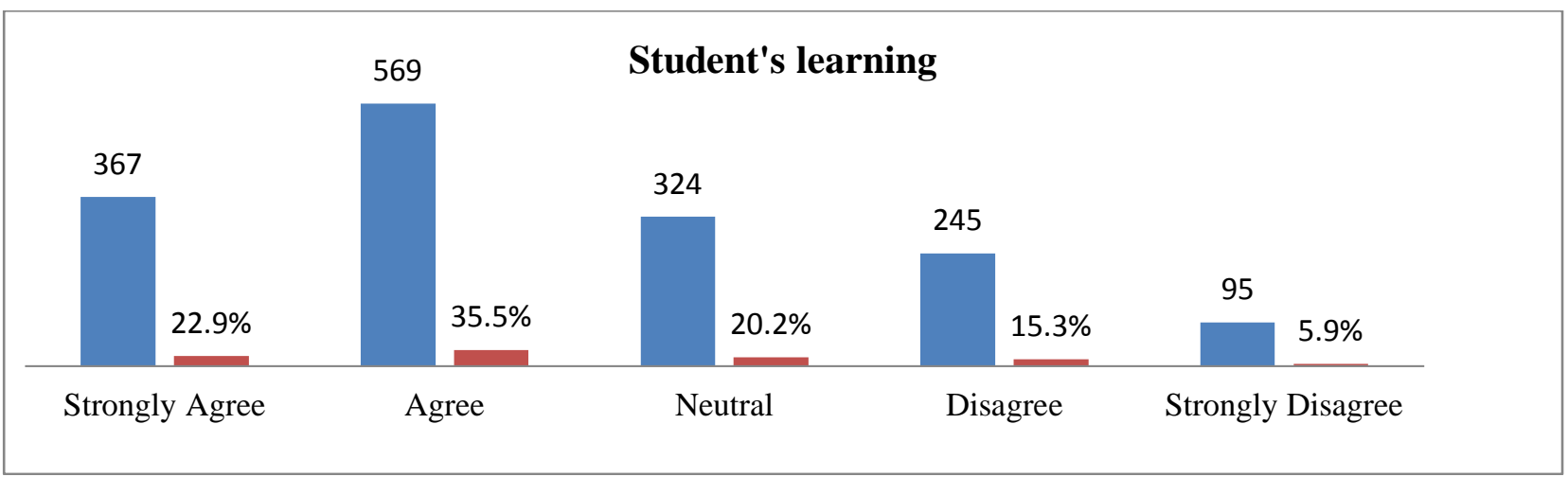

Figure 1:-Scores of teacher's responses about students learning.

Table 1 shows that the value of seven statements of Chi-square $\chi^{2}(\mathrm{df}=4)=262.650,56.450,37.150,47.000,61.200$, 35.400 and 79.600. The values of Chi-square of these statements are much higher than the critical values $\chi^{2}(\mathrm{df}=4)$ $=9.49$ at $\mathrm{a}=0.05$. The value of remaining one statement of Chi-square $\chi^{2}(\mathrm{df}=3)=40.360$. The values of Chi-square 
of this statement is also much higher than the critical values $\chi^{2}(\mathrm{df}=3)=7.81$ at a $=0.05$. It means that the eight statements related to area "students learning" are highly accepted. Figure 1 indicates that majority of the teacher's respondents $367(22.9 \%)$ strongly agree and $569(35.5 \%)$ agreed that the students learning is better in mono-grade teaching strategies. It illustrates that most of the respondents accepted these statements related to the said area.

Table 2:-Scores of teacher's responses regarding teaching methodology.

\begin{tabular}{|c|c|c|c|c|c|c|c|c|c|}
\hline \multirow[t]{2}{*}{ Aspects } & \multirow[t]{2}{*}{ SA } & \multirow[t]{2}{*}{ A } & \multirow[t]{2}{*}{$\mathrm{N}$} & \multirow[t]{2}{*}{ DA } & \multirow[t]{2}{*}{ SDA } & \multirow[t]{2}{*}{$\mathrm{N}$} & \multirow[t]{2}{*}{ Df } & \multicolumn{2}{|c|}{ Chi-Square } \\
\hline & & & & & & & & $\chi^{2}$ & Sig \\
\hline $\begin{array}{l}\text { Teaching provides opportunity for the } \\
\text { enhancement of learning by the lower grade } \\
\text { level group through exposure to upper grade } \\
\text { level students }\end{array}$ & 68 & 85 & 20 & 21 & 6 & 200 & 4 & 118.150 & .000 \\
\hline $\begin{array}{l}\text { Teaching provides opportunity for students to } \\
\text { learn through peer tutoring }\end{array}$ & 55 & 81 & 24 & 26 & 14 & 200 & 4 & 75.850 & .000 \\
\hline $\begin{array}{l}\text { Is teaching encourage students to participate in } \\
\text { group studies }\end{array}$ & 61 & 94 & 22 & 20 & 3 & 200 & 4 & 136.250 & .000 \\
\hline Is teaching is easier by approach & 62 & 99 & 24 & 10 & 5 & 200 & 4 & 158.650 & .000 \\
\hline $\begin{array}{l}\text { Assessment is easier in grade teaching } \\
\text { approach }\end{array}$ & 62 & 97 & 22 & 13 & 6 & 200 & 4 & 148.550 & .000 \\
\hline Teaching is not an inferior strategy of teaching & 60 & 90 & 27 & 16 & 7 & 200 & 4 & 118.350 & .000 \\
\hline $\begin{array}{l}\text { Teachers of grade classes are inadequately } \\
\text { prepared for teaching such classes }\end{array}$ & 43 & 34 & 87 & 23 & 13 & 200 & 4 & 81.800 & .000 \\
\hline $\begin{array}{l}\text { Teachers of grade classes are inadequately } \\
\text { prepared for teaching such classes }\end{array}$ & 43 & 34 & 87 & 23 & 13 & 200 & 4 & 81.800 & .000 \\
\hline $\begin{array}{l}\text { Grade class is considerably more difficult to } \\
\text { teach }\end{array}$ & 16 & 17 & 68 & 52 & 47 & 200 & 4 & 52.050 & .000 \\
\hline Is teaching, too demanding in modern age & 53 & 95 & 43 & 8 & 1 & 200 & 4 & 143.700 & .000 \\
\hline Teaching is an innovation & 68 & 91 & 29 & 10 & 2 & 200 & 4 & 146.250 & .000 \\
\hline & 548 & 783 & 366 & 199 & 104 & 2000 & & & \\
\hline
\end{tabular}

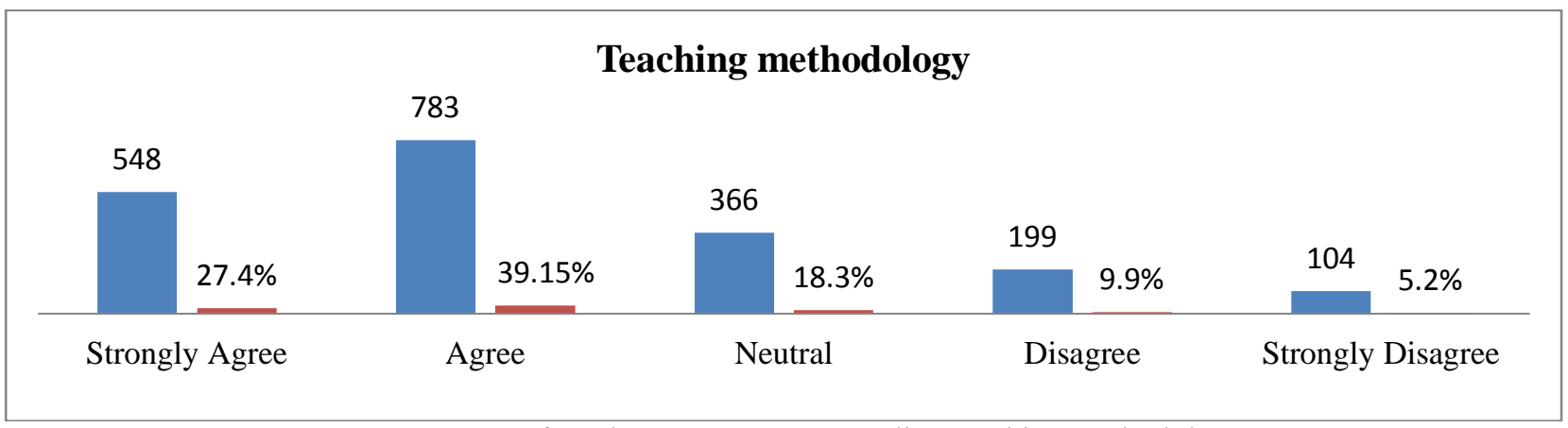

Figure 2:-Scores of teacher's responses regarding teaching methodology.

Table 2 shows that the value of ten statements of Chi-square $\chi^{2}(\mathrm{df}=4)=118.150,75.850,136.250,158.650$, $148.550,118.350,81.800,52.050,143.700$ and 146.250. The values of Chi-square of these statements are much higher than the critical values $\chi^{2}(\mathrm{df}=4)=9.49$ at $\mathrm{a}=0.05$. It means that the ten statements related to area "teaching methodology" are highly accepted. Figure 2 indicates that majority of the teachers' respondents $548(27.4 \%)$ strongly agree and 783(39.15\%) agreed that the teaching methodology is better in mono-grade teaching strategies. It illustrates that most of the respondents accepted these statements related to the said area.

Table 3:-Scores of teacher's responses regarding students participation in Multi-grade teaching

\begin{tabular}{|c|c|c|c|c|c|c|c|c|c|}
\hline Aspects & SA & A & N & DA & SDA & N & Df & \multicolumn{2}{|c|}{ Chi-Square } \\
\cline { 5 - 10 } & & & & & & & & $\chi^{2}$ & Sig \\
\hline Teaching is concerned student's social skill & 26 & 40 & 41 & 80 & 13 & 200 & 4 & 63.150 & .000 \\
\hline
\end{tabular}




\begin{tabular}{|l|c|c|c|c|c|c|c|c|c|}
\hline development & & & & & & & & & \\
\hline $\begin{array}{l}\text { Provides reinforcement of earlier learning for } \\
\text { the upper grade level students }\end{array}$ & 14 & 28 & 37 & 71 & 50 & 200 & 4 & 47.250 & .000 \\
\hline $\begin{array}{l}\text { In teaching grouping the students according to } \\
\text { their abilities }\end{array}$ & 17 & 26 & 38 & 72 & 47 & 200 & 4 & 45.050 & .000 \\
\hline $\begin{array}{l}\text { In teaching it is easier for students to learn what } \\
\text { others are taught }\end{array}$ & 45 & 69 & 34 & 46 & 6 & 200 & 4 & 52.350 & .000 \\
\hline $\begin{array}{l}\text { Is teaching engaging upper grades students to } \\
\text { support lower grade students }\end{array}$ & 15 & 47 & 31 & 63 & 44 & 200 & 4 & 32.500 & .000 \\
\hline $\begin{array}{l}\text { In teaching, there is lower time on task for } \\
\text { students }\end{array}$ & 23 & 34 & 7 & 43 & 93 & 200 & 4 & 105.800 & .000 \\
\hline $\begin{array}{l}\text { In teaching, there is less time for direct } \\
\text { instructions }\end{array}$ & 26 & 19 & 41 & 58 & 56 & 200 & 4 & 30.450 & .000 \\
\hline & 166 & 263 & 229 & 433 & 309 & 1400 & & & \\
\hline
\end{tabular}

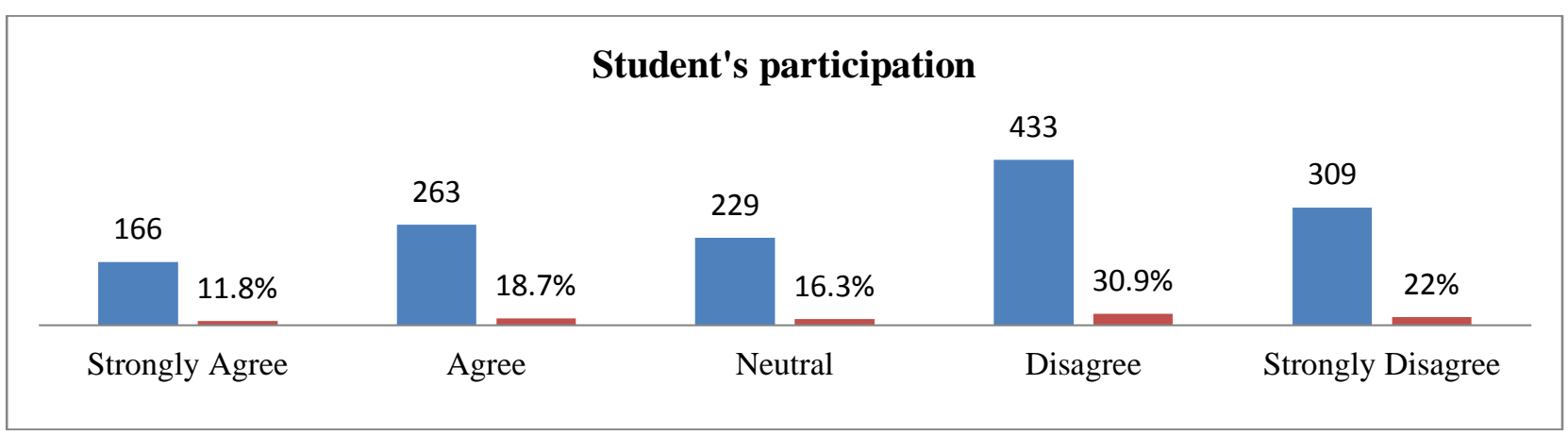

Figure 3:-Scores of teacher's responses regarding student's participation in Multi-grade teaching.

Table 3 shows that the value of seven statements of Chi-square $\chi^{2}(\mathrm{df}=4)=63.150,47.250,45.050,52.350,32.500$, 105.800 and 30.450. The values of Chi-square of these statements are much higher than the critical values $\chi^{2}(\mathrm{df}=4)$ $=9.49$ at $\mathrm{a}=0.05$. It means that the seven statements related to area "student's participation in multi-grade teaching" are highly rejected. Figure 3 indicates that majority of the teachers' respondents $433(30.9 \%)$ strongly disagree and $309(22 \%)$ disagreed that the student's participation in multi-grade teaching is not better teaching strategies. It illustrates that most of the respondents rejected these statements related to the said area.

Table 4:-Scores of teacher's responses regarding teaching difficulties/problems.

\begin{tabular}{|l|c|c|c|c|c|c|c|c|c|}
\hline \multicolumn{1}{|c|}{ Aspects } & SA & A & N & DA & SDA & N & Df & \multicolumn{2}{|c|}{ Chi-Square } \\
\hline $\begin{array}{l}\text { Teachers do not have learning materials for } \\
\text { their teaching in classes }\end{array}$ & 11 & 28 & 30 & 71 & 60 & 200 & 4 & 61.150 & .000 \\
\hline $\begin{array}{l}\text { Teacher used the local available materials as } \\
\text { teaching aids }\end{array}$ & 62 & 85 & 28 & 17 & 8 & 200 & 4 & 105.150 & .000 \\
\hline $\begin{array}{l}\text { Teacher students ratio is less in multi-grade } \\
\text { classes }\end{array}$ & 13 & 20 & 30 & 70 & 67 & 200 & 4 & 71.450 & .000 \\
\hline $\begin{array}{l}\text { Teaching and learning materials for multi-grade } \\
\text { classes are adequately available }\end{array}$ & 75 & 85 & 22 & 10 & 8 & 200 & 4 & 137.450 & .000 \\
\hline & 161 & 218 & 110 & 168 & 143 & 800 & & & \\
\hline
\end{tabular}




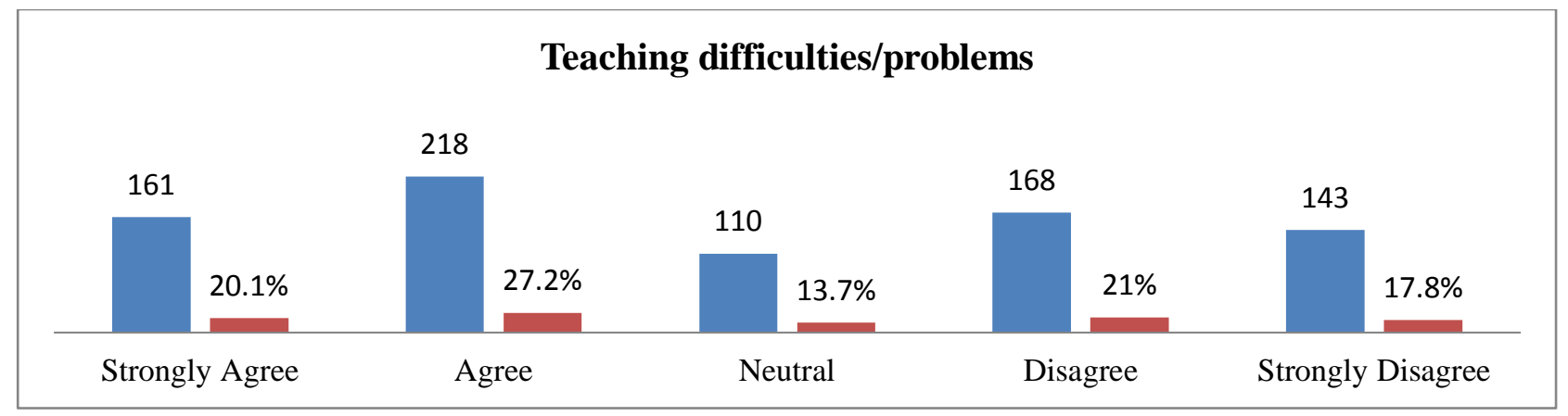

Figure 4:-Scores of teacher's responses regarding teaching difficulties/problems.

Table 4 shows that the value of four statements of Chi-square $\chi^{2}(\mathrm{df}=4)=61.150,105.150,71.450$ and 137.450 . The values of Chi-square of these statements are much higher than the critical values $\chi^{2}(\mathrm{df}=4)=9.49$ at $\mathrm{a}=0.05$. It means that the four statements related to area "teaching difficulties/problems" are highly accepted. Figure 4 indicates that majority of the teachers' respondents 161(20.1\%) strongly agree and $218(27.2 \%)$ agreed that no teaching difficulties/problems in mono-grade teaching strategies. It illustrates that most of the respondents accepted these statements related to the said area.

Table 5:-Scores of teacher's responses regarding parental approaches.

\begin{tabular}{|l|c|c|c|c|c|c|c|c|c|}
\hline \multicolumn{1}{|c|}{ Aspects } & SA & A & N & DA & SDA & N & Df & \multicolumn{2}{c|}{ Chi-Square } \\
\cline { 4 - 10 } & & & & & & & & $\chi^{2}$ & Sig \\
\hline $\begin{array}{l}\text { Parents like multi-grade or mono-grade } \\
\text { teaching approaches }\end{array}$ & 50 & 61 & 44 & 37 & 8 & 200 & 4 & 39.750 & .000 \\
\hline $\begin{array}{l}\text { Is grade, teaching is less expensive for } \\
\text { community to organize }\end{array}$ & 19 & 21 & 27 & 82 & 51 & 200 & 4 & 71.400 & .000 \\
\hline $\begin{array}{l}\text { In teaching, you think that distance education } \\
\text { is credible }\end{array}$ & 72 & 88 & 21 & 12 & 7 & 200 & 4 & 139.050 & .000 \\
\hline $\begin{array}{l}\text { Teaching is able to cope with parental concern } \\
\text { about effects of grades placement }\end{array}$ & 70 & 82 & 21 & 19 & 8 & 200 & 4 & 112.250 & .000 \\
\hline & 211 & 252 & 113 & 150 & 74 & 800 & & & \\
\hline
\end{tabular}

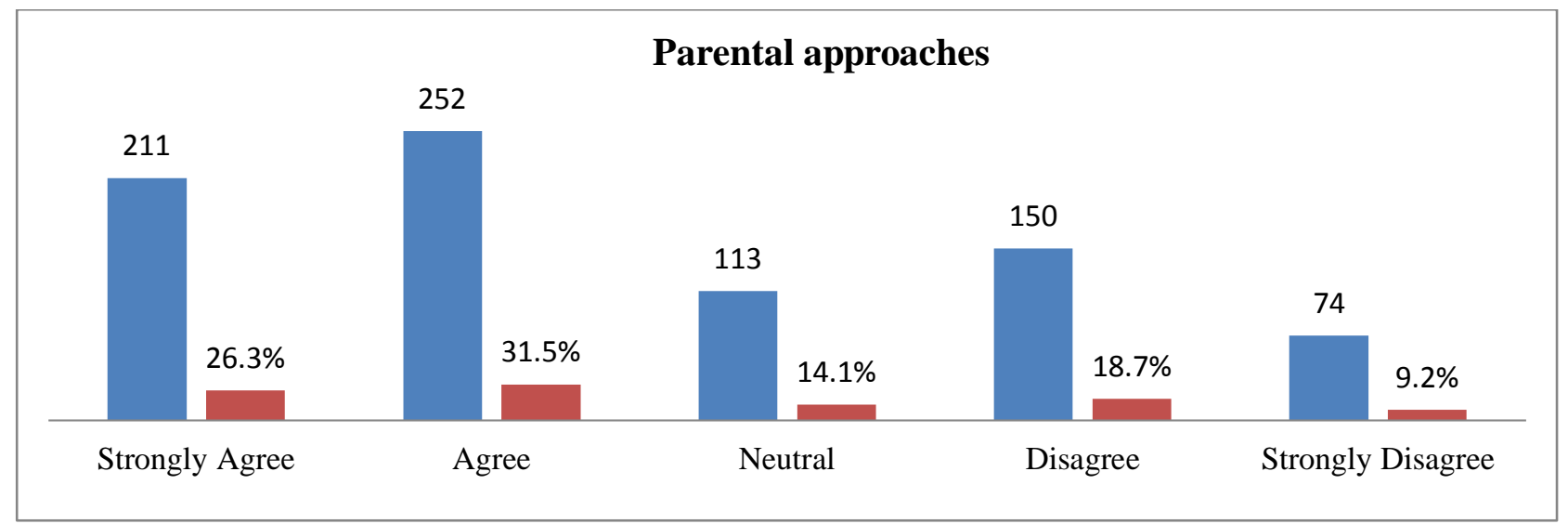

Figure 5:-Scores of teacher's responses regarding parental approaches.

Table 5 shows that the value of four statements of Chi-square $\chi^{2}(\mathrm{df}=4)=39.750,71.400,139.050$ and 112.250 . The values of Chi-square of these statements are much higher than the critical values $\chi^{2}(\mathrm{df}=4)=9.49$ at $\mathrm{a}=0.05$. It means that the four statements related to area "parental approaches" are highly accepted. Figure 5 indicates that majority of the teachers' respondents $211(26.3 \%)$ strongly agree and $252(31.5 \%)$ agreed that the parental approaches are much high in mono-grade teaching strategies. It illustrates that most of the respondents accepted these statements related to the said area. 
Table 6:-Scores of teacher's responses regarding working conditions of schools.

\begin{tabular}{|c|c|c|c|c|c|c|c|c|c|}
\hline \multirow[t]{2}{*}{ Aspects } & \multirow[t]{2}{*}{$\mathrm{SA}$} & \multirow[t]{2}{*}{ A } & \multirow[t]{2}{*}{$\mathrm{N}$} & \multirow[t]{2}{*}{ DA } & \multirow[t]{2}{*}{ SDA } & \multirow[t]{2}{*}{$\mathrm{N}$} & \multirow[t]{2}{*}{ Df } & \multicolumn{2}{|c|}{ Chi-Square } \\
\hline & & & & & & & & $\chi^{2}$ & Sig \\
\hline $\begin{array}{l}\text { Working condition of your school is } \\
\text { satisfactory }\end{array}$ & 87 & 99 & 12 & 2 & 0 & 200 & 3 & 150.360 & .000 \\
\hline $\begin{array}{l}\text { Grade teaching in multi-grade schools be } \\
\text { abolished }\end{array}$ & 79 & 89 & 17 & 10 & 5 & 200 & 4 & 164.400 & .000 \\
\hline $\begin{array}{l}\text { Is teaching, benefits the multi-grades schools } \\
\text { for students }\end{array}$ & 16 & 28 & 29 & 70 & 57 & 200 & 4 & 50.750 & .000 \\
\hline $\begin{array}{l}\text { Multi-grade is more actively bases that mono- } \\
\text { grade approach }\end{array}$ & 71 & 83 & 30 & 15 & 1 & 200 & 4 & 126.400 & .000 \\
\hline \multirow[t]{2}{*}{$\begin{array}{l}\text { Teacher can pay attention to every student in } \\
\text { these grade classes }\end{array}$} & 52 & 75 & 47 & 22 & 4 & 200 & 4 & 75.950 & .000 \\
\hline & 305 & 374 & 135 & 119 & 67 & 1000 & & & \\
\hline
\end{tabular}

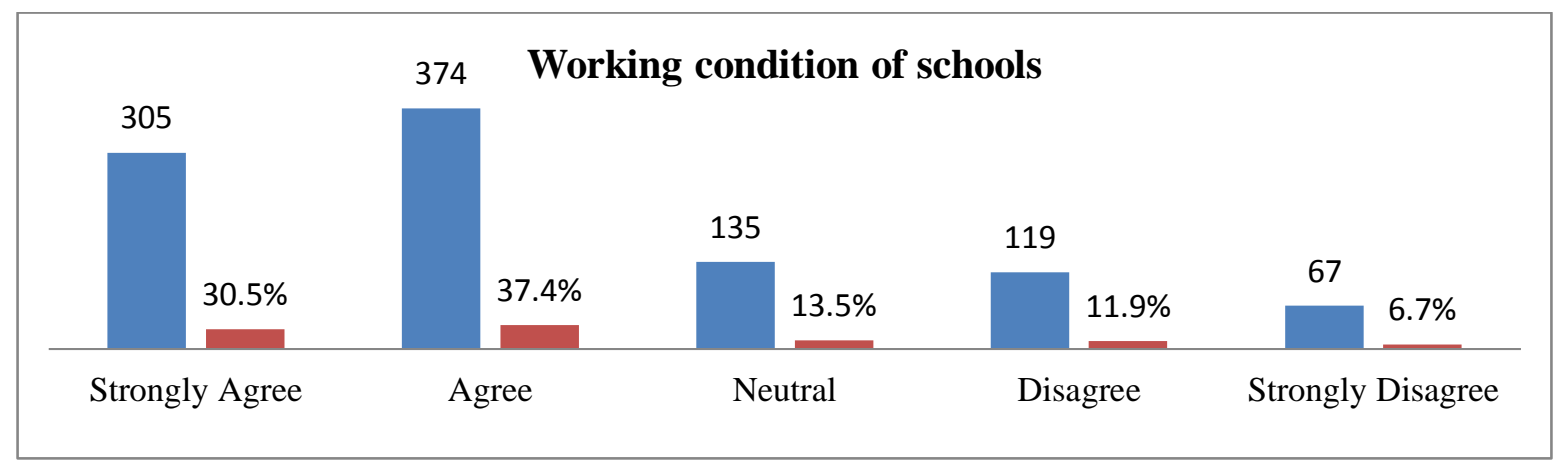

Figure 6:-Scores of teacher's responses regarding working conditions of schools.

Table 6 shows that the value of four statements of Chi-square $\chi^{2}(\mathrm{df}=4)=164.400,50.750,126.400$ and 75.950 . The values of Chi-square of these statements are much higher than the critical values $\chi^{2}(\mathrm{df}=4)=9.49$ at $\mathrm{a}=0.05$. The value of remaining one statement of Chi-square $\chi^{2}(\mathrm{df}=3)=150.360$. The values of Chi-square of this statement is also much higher than the critical values $\chi^{2}(\mathrm{df}=3)=7.81$ at $\mathrm{a}=0.05$. It means that the five statements related to area "working condition of schools" are highly accepted. Figure 6 indicates that majority of the teachers' respondents $305(30.5 \%)$ strongly agree and 374(37.4\%) agreed that the working conditions of the schools is better in monograde teaching strategies. It illustrates that most of the respondents accepted these statements related to the said area.

\section{Discussion:-}

The purpose of the study was to determine the effects of mono-grade method of teaching and learning at primary lever schools. The study results and findings reveal that in mono-grade method of teaching strategies the responses of the study indicated high association among the mono-grade method of teaching. The association specified the greater support to mono-grade method of teaching strategies. In research study of Tomlinson (2005) it is indicated that the more familiar mono-grade classes, have an educational theory of differentiated instruction that responds to the individual needs of each student in the class.

1. The study revealed that the perception of the responses about the student learning in mono-grade method of teaching strategies is statistically high the majority of responses had high positive perception. The mono-grade classes have an educational theory of differentiated instruction that responds to the individual needs of each student in the class (Tomlinson, 2005). The mono-grade classes are rigid educational structures (Cornish, 2006),

2. About the teaching methodology in mono-grade method of teaching the teacher's responses were quite significant and more teachers are supporting to mono-grade method of teaching. In studies of Cornish (2009), Gnadinger (2008), revealed that in modern era mono-grade classrooms, the basic philosophy of classroom organization.

3. In student participations in mono-grade classes, the responses opinions about the mono-grade participation remain high and responses are agreed that the learning outcome in mono-grade strategy is better. It is also proved in the study of Higgins (2005), who observed that the finding of the teachers in mono-grade teaching strategy were high positive perception. It is supported by the comprise studies of Kappler and Roellke (2002) 
that the finding of the results of student achievement in multi-grade classrooms compared to that in mono-grade classrooms vary.

4. In teacher's opinion regarding the teaching difficulties in mono-grade method of teaching strategy quite often. In other research the multi-grade class structure is a more difficult, complex and challenging one than that provided by the single-grade structure (Mason \& Burns, 1995, 1996; Mason \& Doepner, 1998; Veenman, 1995, 1996; Veenman \& Raemaekers, 1995).

5. About the parental approaches in the mono-grade teaching the response of teacher reflect quite high that mean teacher's supporting that the learning motivation in mono-grade teaching is better. The current study supported by the previous research of Cornish (2009) that the social interaction continues to be an important part of the educational process. It is also observed in the studies of Tomlinson and Henderson (2005), Rouse and Barrow (2006) that the societal, parental and educational factors influence student learning. In study of Myrberg and Rosen (2008) it reflects that the parental education as an effect on student achievement. Parental education levels, which include the number of resources in the home and attention to literacy has an association with children's achievements in school. In another research study of Cheadle (2008), the scio-economic status factor has long had an influence on student achievement.

6. The working conditions of their schools, the teacher's perception about the mono-grade class rooms are quite satisfactory. Professional satisfaction derives from things that are intrinsic to the nature of the teacher's work, such as the affective rewards of being with children, perceived professional competence/efficacy, the extension of skills, and the feeling of being in control of one's professional life (Nias, 1989).

\section{Conclusion:-}

On the basis of results and findings the following conclusion was drawn:-

1. That the response of the teacher's about the student learning in mono-grade method of teaching strategies is statistically very high the majority of teachers had high positive perception.

2. About the teaching methodology in mono-grade method of teaching the teacher's responses were quite significant and more teachers are supporting to mono-grade method of teaching.

3. In student participations in mono-grade classes, the teacher's opinions about the mono-grade participation remain high and teachers are agreed that the learning outcome in mono-grade strategy is better.

4. The teacher's response about the teaching difficulties in mono-grade teaching strategy quite often.

5. About the parental approaches in the mono-grade teaching the response of teacher reflect very high that mean teacher's supporting that the learning motivation in mono-grade teaching is better.

6. The working conditions of their schools, the teacher's perception about the mono-grade class rooms are quite satisfactory.

The opinion of the responses is that in mono-grade method of teaching at primary level, students can enhance their increased access to education, improved their performance, develop their social skills, by this method provide opportunities to students to enhance their learning, provides reinforcement of earlier learning, easier for students to taught more, enhance students grades, students will be more motivated in learning, class syllabus can be completed in time, teacher can pay attention to every student, this method fulfill parents demands of modern age, students learn in less time by mono-grade method, promoting group work collaboration, teaching is easier, teacher can pay more attention to students and parents also like mono-grade method of teaching significantly.

\section{Recommendations:-}

The following recommendations are offered to related research in the field of education, which are produced by the outcomes of this study:

1. In this modern age, the study recommended that in all private and governmental institutions, have to apply mono-grade method of learning for students, as by applying this method our educational level will influence by more learning, will clear concepts of students and will also be helpful to improve their study level as well as they can speak confidently about their learning.

2. In multi-grade classes, there is less scope of learning for junior grade classes in the presence of senior students, junior students get confuse and afraid of by their seniors, hence mono-grade method of teaching is recommended for this level.

3. In a multi-grade class teachers were unable to give full attention to all students. So mono-grade method is being recommended for this aspect. 
4. Mono-grade classrooms should tend to be characterized by undifferentiated whole class teaching, in multi-grade classes student should have more opportunity to engage small group work.

5. For the ease of teachers to pay full attention to all the students in populated class the mono-grade method of teaching is being recommended.

6. This is also recommended for the provision of enhancement of our educational system to slowly upgrade to international standards for the progressive future of students.

\section{Recognition:-}

The researcher did not receive any ordinary, special and specific grant from any funding agency in the, commercial, public or not-for-profit sectors.

\section{References:-}

1. Aksoy, N., (2007). Multi-grade schools in Turkey: An overview. International Journal of Educational Development.

2. APEID/UNESCO, (1989). Multi-grade teaching in single teacher primary schools. Asia and the Pacific programme of Educational innovation and development. UNESCO Principal Regional office for Asia and the Pacific Bangkok, Thailand.

3. Berry, C., (2001). Achievements effects of multi-grade and mono-grade primary schools in the Turks and Caicos Islands. International Journal of Education Development, 21(6): 561-566.

4. Berry, C., \& Little, A. W. (2006). Multi-grade teaching in London, England. In A. W. Little (Ed.), Education for all and multi-grade teaching: Challenges and opportunities (pp. 67-86). Netherlands: Springer.

5. Best, J.W, \& Kahn, J.V., (1998). Research in Education (8 ${ }^{\text {th }}$, Ed) Boston; Allyn and Bacon.

6. Bhardwaj, N. (2008). Multi-grade teaching. New Delhi, India: APH Publishing

7. Blum, N. \& Diwan, R., (2007). Small, multi-grade schools and increasing access to primary education in India: National context and NGO initiatives. Consortium for Research on Educational Access, Transitions \& Equity.

8. Borg, W. R. \& Gall, M. D., (1986). Educational Research, Longman: New York.

9. Borg, W. R. \& Gall, M. D., (1989). Educational Research: An Introduction 5th. Eden. New York: Longman.

10. Borg, W. R. \& Gall, M. D., (1998). Educational Research: An Introduction 5th. Eden. New York: Longman.

11. Brinegar, K., (2010). 'I feel like I'm safe again:' A discussion of middle grades organizational structures from the perspective of immigrant youth and their teachers. Research in Middle Level Education, 33(9), 1-14.

12. Burns, R. B. and D. A. Mason (1998). "Class Formation and Composition in Elementary Schools." American Educational Research Journal 35(4): 739-772.

13. Chapman, M. L. (1995). Designing literacy learning experiences in a multiage classroom. Language Arts, 72(6), 416-428.

14. Cheadle, J. E. (2008). Educational investment, family context, and children's math and reading growth from Kindergarten through the Third Grade. Sociology of Education, 81(January), 1-31.

15. Cornish, L. (2006). Parents views of composite classes in an Australian primary school. The Australian Educational Researcher, 33(2), 123-142.

16. Cornish, L., (2009). Teaching the world's children: Theory and practice in mixed-grade classes. Paper presented at the International Symposium for Innovation in Rural Education, Armidale, Australia.

17. De Vos, A. S., Strydom, H., Fouche, C. B., \& Delport, C. S. L., (1998). Research at grass roots. Pretoria: Van Schaik.

18. Dewey, J. (1916). Democracy and education. An introduction to the philosophy of education. (1966 Ed.). New York: Free Press.

19. Fawcett, L. M., \& Garton, A. F. (2005). The effect of peer collaboration on children's problem-solving ability. British Journal of Educational Psychology, 75, 157-169. DOI: 10.1348/000709904X23411

20. Fosco, A. M., Schleser, R., \& Andal, J., (2004). Multiage programming effects on cognitive development level and reading achievement in early elementary school children. Reading Psychology an international quarterly, 25(1), 1-17.

21. Gay, L. R., (1976). Education Research: Competencies for Analysis and Application. Ohio: Merill Publishers, Co. of Teaching in Kenya. Implications for Teacher Induction Policies and Programmes. In Journal of InService Education. An International Journal of Professional Development. Edited by Tony Bates, Thompson and Marion.

22. Gay, L. R., (1987). Educational Research: Competencies for Analysis and Application. 3rd.edn. London: Merrill Publishing. 
23. Gay, L.R., (2002). Educational Research: Competencies for Analysis and Application, National Book Foundation, Lahore.

24. Gene, B. S. 2005. The case of Universal Basic Education for the world poorest boys and girls. Phi Delta Kappon: Cambridge Education

25. Gnadinger, C. M. (2008). Peer-mediated instruction: Assisted performance in the primary classroom. Teachers and Teaching: Theory and Practice, 14(2), 129-142.

26. Higgins, C. (2005). Multi-grade Teaching; A Viable Option for Sub-Saharan Africa? Retrieved 01-12-2009 at amulkeen@worldbank.org

27. Jordaan, V., \& Joubert, J. (2007). Training of teachers in poor rural areas through a multi-grade intervention to achieve millennium development goals: Our experience of using ODL as a tool for building capacity and what lessons can be learned? Wellington, South Africa: Cape Peninsula University of Technology.

28. Joubert, J. 2010. Multi-grade teaching in South Africa. Commonwealth Education Partnership.

29. Kappler, E., \& Roellke, C., (2002). The promise of multiage grouping. Kappa Delta Pi Record, 38(4), 165-169.

30. Little, A., (1995). Multi-grade teaching: A review of practice and research. Education Research, Serial No. 12. London: Overseas Development Administration.

31. Little, A. W., (2001). Multi-grade teaching: Towards an international research and policy agenda. International Journal of Educational Development. p. 481-497.

32. Little, A. W. (2004a). Learning and teaching in multi-grade setting. Background paper for the Global Monitoring Report. Available Online. http://portal.unesco.org (accessed 05 March 2010).

33. Little, A.W. (2004b). Learning and teaching in multi-grade settings. Background paper prepared for the Education for All Global Monitoring Report 2005, The Quality Imperative. United Nations Educational, Scientific and Cultural Organization.

34. Little, A.W. (ed.) (2006) Education for All and Multi-grade Teaching: Challenges and Opportunities. Dordrecht: Springer

35. Little, A. W., (2007). PRIDMORE, P., BAJRACHARYA, H. \& ITHANAPHATHIVANA, M. Learning and teaching in multi-grade settings. A final report to DFID.

36. Little, A., (2008). Increasing access through multi-grade teaching and learning. Consortium for Research on Education, Access, Transitions \& Equity. Saarbrücken: Lambert Academic Publishing.

37. Lloyd, L., (2002). Multiage classes: What research tells us about their suitability for rural schools? Education in Rural Australia, 12(2), 1-14.

38. LoBiondo-Wood, G., \& Haber, J., (1998). Nursing research: Methods and critical appraisal for evidence-based practice. Elsevier Health Sciences.

39. Lockheed, M. (1991). Improving primary education in developing countries: A review of policy options, Washington: World Bank.

40. Makoelle T M 2013. Exploring Teaching Practices that are Effective in Promoting Inclusion in South African Secondary Schools. PhD Thesis, Unpublished. Manchester: University of Manchester.

41. Mason, D. A. \& Burns, R. B. (1995). Teachers' views of combination classes. Journal of Educational Research, $89(1), 36-45$.

42. Mason, D. A., \& Burns, R. B., (1996). 'Simply no worse and simply no better' may simply be wrong: A critique of Veenman's conclusion about multi-grade classes. Review of Educational Research, 66(3), 307-322.

43. Mason, D. A. \& Doepner, R. W. (1998). Principals' views of combination classes. Journal of Educational Research, 91(3), 160-172.

44. Mirvaliev, M., (1987). The components of chi-squared statistics for goodness-of-fit tests. J. Sov. Math. 38, 2357-2363.

45. Mugenda, O.M and Mugenda A.G, (2003). Research Methods: Quantitative and Qualitative Approaches; Nairobi: African Centre for Technology Studies

46. Mulryan-Kyne, C., (2007). The preparation of teachers for multi-grade teaching. Teaching and Teacher Education: An International Journal of Research and Studies, 23(4), 501-514.

47. Myburgh, C. P. H. \& Strauss, J., (2000). Study Guide: Research Methodology Module 4: Bachelor of Education (B Ed), Training and Development. National Qualification Framework (NQF) Level 7. RAU: Auckland Park.

48. Myrberg, E., \& Rosén, M., (2008). A path model with mediating factors of parents' education on students' reading achievement in seven countries. Educational Research and Evaluation, 14(6), 507-520.

49. Nias, J. (1989). Primary teachers talking: A study of teaching as work. London: Routledge.

50. Pardini, P. (2005). The slowdown of the multiage classroom: What was once a popular approach has fallen victim to NCLB demands for grade-level testing. School Administrator, 62(3), 22-28. 
51. Pilot, D. F., \& Hungler, B. P., (1999). Nursing research: principles and methods. Phildelphia: JB Lippincott Company.

52. Post, D., Van Leeuwen, R., Tiesinga, L. J., Middel, B., \& Jochemsen, H., (2009). The validity and reliability of an instrument to assess nursing competencies in spiritual care. Journal of Clinical Nursing, 18(20), 2857-2869.

53. Pratt, D., (1986). On the merits of multiage classrooms. Research in Rural Education, 3(3), 111-115.

54. Reis, S. M., McCoach, D. B., Little, C. A., Muller, L. M., \& Kaniskan, R. B. (2011). The effects of differentiated instruction and enrichment pedagogy on reading achievement in five elementary schools. American Educational Research Journal, 48(2), 462-501.

55. Rouse, C. E., \& Barrow, L. (2006). U.S. elementary and secondary schools: Equalizing opportunity or replicating the status quo? Opportunity in America, 16(2), 99-123. 140

56. Sibli, M.P.M.M., (2003). Primary Mathematics Unit, National Institute of Education, Multi-grade Teaching: an Introduction, Sri Lanka.

57. Stuart, S. K., Connor, M., Cady, K., \& Zweifel, A. (2006). Multiage instruction and inclusion: A collaborative approach. International Journal of Whole Schooling, 3(1), 12-26.

58. Swenson, L. M., \& Strough, J. (2008). Adolescents' collaboration in the classroom: Do peer relationships or gender matter? Psychology in the Schools, 45(8), 715-728.

59. Taole, M. \& Mncube, V. S., (2012). Multi-grade teaching and quality of Education in South African rural schools: Educators" experiences. Study Tribes Tribals, 10 (2): 151-162. Kamla-Raj.

60. Thomas, C. \& Shaw, C., (1992). Issues in the Development of Multi-grade Schools Washington: World Bank.

61. Tsolakidis, C., \& Constantinidi, A., (2006). ICT reinforcing teaching and learning in multi-grade schools.

62. Tomlinson, C. A., (2000). Leadership for differentiating schools and classrooms. Alexandria, VA: Association for Supervision \& Curriculum Development.

63. Tomlinson, C. A., Brighton, C., Hertberg, H., Callahan, C. M., Moon, T. R., Brimijoin, K., Conover, L. A., \& Reynolds, T. (2003). Differentiated instruction in response to student readiness, interest, and learning profile in academically diverse classrooms: A review of literature. Journal for the Education of the Gifted, 27(2/3), 119145 .

64. Tomlinson, C. A. (2005). Grading and differentiation: Paradox or good practice? Theory into Practice. p. 262269.

65. Tsolakidis C. (2010). Multi-grade issues: a policy required. Unpublished paper presented at the Southern African Conference for Multi-grade Education, Paarl, South Africa, 22 to 24 March.

66. Tustin, D. H., (2006). Business Research. Study guide for CBURESX. Pretoria: University of South Africa.

67. UNICEF, (1998). An evaluation of the multi-grade and bilingual education project. Hanoi, UNICEF

68. UNESCO, (1989). Multi-grade teaching in single teacher primary schools. Asia and the Pacific programme of Educational innovation and development. UNESCO Principal Regional office for Asia and Pacific Bangkok, Thailand.

69. Veenman, S., \& Raemaekers, J. (1995). Long-term Effects of a Staff Development Programme on Effective Instruction and Classroom Management for Teachers in Multi-grade Classes. Educational Studies, 21(2), 167185.

70. Veenman, S., (1995). Cognitive and non-cognitive effects of multi-grade and multi-age classes: A best evidence synthesis, Review of Educational Research. 65 (4), p. 319 - 381.

71. Veenman, S., (1996). Effects of multi-grade and multi-age classes reconsidered. Review of Educational Research, 66(3), 323-340.

72. Vincent, S., Eds., (1999). The Multi-grade Classroom: A resource handbook for small, rural schools. Oregon: Northwest Regional Educational Laboratory.I

73. Vygotsky, L. S. (1978). Mind in society: The development of higher psychological processes (M. Cole, V. John-Steiner, S. Scribener, \& E. Souberman, Eds. \& Trans.). Cambridge, MA: Harvard University Press.

74. Wallace, J.C., Mcnish, H. \& Allen, J. Eds., (2001). A handbook for teachers of multi-grade classes. UNESCO.Ag 2 i communication, Volume one. France.

75. Wood, K, \& Frid, S., (2005). Early childhood numeracy in a multiage setting. Mathematics Education Research Journal, 16(3), 80-99.

76. WALTERS, R. 1991. School Management in teaching practice 1: Method for student teachers. Maskew Miller Longman. 